\title{
Three Ancient Reports of Near-Death Experiences: Bremmer Revisited
}

\author{
Marinus van der Sluijs, M.A. \\ London, United Kingdom
}

\begin{abstract}
In the modern literature, the so-called 'vision of Er,' told by Plato, and the 'vision of Thespesius,' recorded by Plutarch, have sometimes been cited as examples of ancient near-death experiences (NDEs). However, in a recent study, classicist Jan Bremmer (2002) impugned this interpretation. In this article, I offer a fresh analysis of these two texts that challenges Bremmer's stance and that vindicates the similarity between the ancient reports and modern NDEs. The vision of Er emerges as the oldest known direct account of an NDE. I add to these cases Plutarch's description of the 'vision of Timarchus' as an example of an ancient NDE provoked by extreme isolation. Comparison of these reports of NDEs from antiquity with modern analogues suggests a few additional characteristic traits of NDEs.
\end{abstract}

KEY WORDS: near-death experience; visions; underworld; antiquity; Plato; Plutarch.

By a near-death experience (NDE), medical professionals understand a range of experiences obtained by some people during a close brush with death, such as near-drowning, a fall, a traffic accident, or clinical death when any measurable activity in the heart or brain has ceased yet a recovery is made and the person regains the ability to communicate. Irrespective of one's interpretation of these experiences, typical elements include a feeling of being detached from the body and

\footnotetext{
Marinus van der Sluijs, M.A., is a historical and comparative linguist specializing in the Indo-European and Semitic language families. Researching the history of astronomy and religions, cultural astronomy, and comparative mythology, Mr. van der Sluijs is a Consulting Scholar with the University of Pennsylvania Museum of Archaeology and Anthropology. Correspondence regarding this article should be directed to Mr. van der Sluijs at Beetwortelweg 37, 3263 EA, Oud-Beijerland, The Netherlands; e-mail: mythopedia@hotmail.com.
} 
floating above it; the absence of pain; presence in a dark, enclosed space; rapid movement towards a wonderfully bright light; arrival in a paradise-like place; communication with deceased people; a desire to stay; and often a forced return into the body (Moody, 1975; Moody \& Perry, 1988, pp. 2, 6-15; Noyes \& Kletti, 1976; Ring, 1980, pp. 39-66; van Lommel, 2007, pp. 39, 44-64). Since Raymond Moody first coined the term near-death experience in 1975 (p. 14), a number of reports from ancient and medieval sources - often couched in terms of mystical or religious visions - have been cited as evidence for NDEs in historical times (Baal Shem Tov, 1972, p. 4; Bremmer, 2002, pp. 87102; Moody, 1975, pp. 111-119; Platthy, 1992; van Lommel, 2007, pp. 305-306, 316; Zaleski, 1987), yet none of the candidates from classical literature were analyzed at sufficient depth or widely acknowledged by classicists. Notable among these are two Greek descriptions of 'visits to the other world,' which are attributed to two otherwise unknown people identified as Er the Pamphylian and Aridaeus or Thespesius of Soli.

The source for the earlier of these accounts is a speech by Socrates, incorporated in Plato's Republic (1946, pp. 490-519; 10. 13-16 [614B$621 \mathrm{C}])$. Socrates related the fate of "a warrior bold" called "Er, the son of Armenius, by race a Pamphylian" (p. 491), who was left for dead on the battlefield but unexpectedly returned to life at the instant he was placed on the funeral pyre:

He once upon a time was slain in battle, and when the corpses were taken up on the tenth day already decayed, was found intact, and having been brought home, at the moment of his funeral, on the twelfth day as he lay upon the pyre, revived, and after coming to life related what, he said, he had seen in the world beyond. (pp. 491, 493)

In brief, Er reflected that "when his soul went forth from his body he journeyed with a great company," which proceeded towards a meadow portrayed as "a mysterious region where there were two openings side by side in the earth" (p. 493) through which the souls of disembodied people travelled upwards and downwards in space in accordance with the judgment passed on their lives in that place. After an interval of "seven days,"

they were required to rise up on the eighth and journey on, and they came in four days to a spot whence they discerned, extended from above throughout the heaven and the earth, a straight light like a pillar, most nearly resembling the rainbow, but brighter and purer. (pp. 499, 501) 
A detailed description of this radiant pillar bears out that it served as the pivot of the cosmos on which the complex movement of the stars and planets as well as the individual fates of living beings depended. The pillar resembled the shaft of a spindle whorl that "turned on the knees of Necessity" or Anánkē (p. 503), a female deity, assisted by the three Fates or Moirai: Clotho, Atropos, and Lachesis. Having then watched how a bevy of souls selected lots for their next lives and drank from a river that erased their memories, Er was suddenly drawn back towards his body and awoke:

Er himself ... was not allowed to drink of the water, yet how and in what way he returned to the body he said he did not know, but suddenly recovering his sight he saw himself at dawn lying on the funeral pyre. (p. 519)

The second account examined in this article was reported in Plutarch's The Divine Vengeance (1984, pp. 268-299; 22-33 [563D568A]). This account concerned a man from Soli, Cilicia, whose original name was Aridaeus, but who was given the new name of Thespesius in the course of his sojourn in the 'other world.' "He had fallen from a height and struck his neck, and although there had been no wound, but only a concussion, he died away. On the third day, at the very time of his funeral, he revived" (p. 271). Plutarch related that this man, while appearing to be dead, had the sensation that "his intelligence was driven from his body" and that he "had risen somewhat and was breathing with his whole being and seeing on all sides, his soul having opened wide as if it were a single eye" (p. 273). Having familiarized himself with the mobility of his new 'body' and noted the presence of souls of many different types in the elevated environment to which he had ascended, Aridaeus "recognized one soul, that of a kinsman, though not distinctly, as he was but a child when the kinsman died; but it drew near and said: 'Greetings, Thespesius"' (p. 277). This 'guide' then took Thespesius on a tour of the various regions in the 'afterlife.' These regions included "a great chasm extending all the way down ... called the place of Lethe" (p. 285) and another "deep chasm in the ambient" (p. 287; see also Mead, 1907, p. 27) which was "a large crater with streams pouring into it, one whiter than sea-foam or snow, another like the violet of the rainbow, and others of different tints, each having from afar a lustre of its own" ( $p$. 287). Thespesius also saw a region with "those who were suffering punishment" (pp. 291, 293). The "final spectacle of his vision" was that of "the souls returning to a second birth, as they were forcibly bent to 
fit all manner of living things and altered in shape by the framers of these" (p. 297). While he was watching this scene, a "woman interposed, and he was suddenly pulled away as by a cord and cast in a strong and violent gust of wind upon his body, opening his eyes again almost from his very grave" (p. 299).

Dutch classicist Jan Bremmer (2002) is to be commended for his contribution to the study of NDEs in classical literature. However, he has been reluctant to accept the historicity or the reliability of these two reports and their possible interpretation as descriptions of NDEs. With respect to Er, Bremmer asserted that "the incredible, dramatic details of Er's survival surely should read as a warning to the reader of the fictional character of the account, not as an attempt to provide an eye witness report" (p. 90). Bremmer appears to have dismissed the episode as an example of an ancient NDE: "Can this report also count as an NDE? Hardly so. Er ... leaves the body but does not even know how he returned - a detail which presumably was no longer of interest to Plato's purposes" (p. 92). As for Thespesius, Plutarch's (1984) translators, Philip De Lacy and Benedict Einarson, were similarly confident that "Thespesius, the hero of the myth, is doubtless a fiction of Plutarch's. The name was chosen for its meaning, thespesios being often used of things divine and strange" (p. 173). Whereas these authorities did not comment on a possible link with NDEs, Bremmer gave short shrift to this possibility:

Regarding the typical NDE details, we find only the feeling of drifting upwards and the recognition of some of his former acquaintances. In a way, these details are not very specific and the most striking parallel with modern NDEs is that his experience, according to Plutarch, affected his lifestyle .... (p. 94)

As the accounts of Er and Thespesius contain sufficient detail to warrant a reliable assessment, it is worth reassessing both their historicity and their possible entitlement to be treated as cases of NDEs. How can this be done in a systematic way? Experts in the field of neardeath studies, such as Moody (1975), Kenneth Ring (1980), Michael Sabom (1982), and Bruce Greyson (1983), have compiled checklists enumerating recurrent traits with which an NDE can be reliably diagnosed. In a recent publication on this subject, Dutch cardiologist Pim van Lommel (2007, pp. 37-41) offered a convenient overview of these schemes. As van Lommel's work is so far available only in Dutch, references to his work throughout this article represent my translations to English. On the basis of this literature, I have distilled a list of 16 core 
elements that can serve as criteria to evaluate the visions of Er and Thespesius as NDEs. These elements are: difficulty to describe what has been seen; awareness of being dead; out-of-body experience (OBE); sound upon OBE; absence of pain; passage towards a bright light; observation of an otherworldly, beautiful landscape; 'hellish' experience; encounter with deceased people, often including relatives or friends; encounter with a being of light or a guide; life review; flash forward; experience of a boundary; forced return; conscious return to the body; and, following the NDE, changed lifestyle. The "passage towards a bright light" is intended as a more careful and general definition of the proverbial 'tunnel' experience, taking into account Kellehear's (2008) tentative finding that the image of a tunnel per se seems to be limited to modern, Western societies. On a global, intercultural level, it may be more accurate to speak of movement towards a bright light that is often experienced as involuntary; guided or impulsive; involving a notable road, path, or other medium comparable to the tunnel; and frequently characterized by sensations of darkness, narrowness, eeriness, or inconvenience.

\section{The Vision of Er as a Near-Death Experience}

To begin with the vision of Er, that Er must have had an OBE is borne out by his reference to the instant "when his soul went forth from his body" (Plato, 1946, p. 493) and the moment when "he returned to the body" (p. 519).

Second, the signature of an NDE in popular awareness is the socalled 'tunnel experience,' in which "people have the sensation of being pulled very rapidly through a dark space of some kind ... a cave, a well, a trough, an enclosure, a tunnel, a funnel, a vacuum, a void, a sewer, a valley, and a cylinder" (Moody, 1975, pp. 30-31). Upon this experience generally follows "the encounter with a very bright light," which

rapidly gets brighter until it reaches an unearthly brilliance. ... not one person has expressed any doubt whatsoever that it was a being, a being of light. Not only that, it is a personal being. It has a very definite personality. (Moody, 1975, pp. 58-59; see also Moody \& Perry, 1988, p. 11; van Lommel, 2007, p. 52).

The theme is here broadened to the less cultural-specific notion of passage towards a bright light, often experienced as involuntary or 
guided and characterised by sensations of darkness, tightness, or uncanniness. Plato's text does not contain a straightforward description of a tunnel with a bright light at the end, but a parallel to the dramatic journey towards a dazzlingly bright and benign light may be seen in the eventual arrival of Er and the band of accompanying souls at "a spot whence they discerned, extended from above throughout the heaven and the earth, a straight light like a pillar, most nearly resembling the rainbow, but brighter and purer" (Plato, 1946, p. 501). The luminosity of this phenomenon is amply expressed in Plato's use of the terms phos euthý, hoion kína, a "straight light like a pillar;" málista têi íridi prosephe, lampróteron dè kaì katharôteron, "most nearly resembling the rainbow, but brighter and purer;" and adámas, or "adamant" for the material of which it was made, if, by this term, Plato meant 'diamond.' Significantly, Moody and Paul Perry (1988) pointed out that the tunnel through which the experiencer seems to move is not invariably represented as devoid of light but may sport an illuminated interior: "In one of the most amazing tunnel experiences I've ever heard the tunnel was described as being almost infinite in length and width and filled with light" (p. 9). Perhaps the fabulous 'pillar of Er' represented such a radiant variant of the 'tunnel,' even though Er did not actually pass through it.

Third, Er is certainly believed to have encountered a beautiful otherworldly landscape, such as is often stated in reports of NDEs to feature beautiful colors, flowers, and music (e.g., Moody \& Perry, 1988, p. 10). Plato's (1946, pp. 494-495, 498-499) text portrayed this landscape as a leimón, "meadow," on which the souls participated en panēgýrei, in a joyous "festival:"

Those which arrived from time to time appeared to have come as it were from a long journey and gladly departed to the meadow and encamped there as at a festival ... But when seven days had elapsed for each group in the meadow, they were required to rise up on the eighth and journey on. (pp. 495, 499)

Fourth, a meeting with other souls of deceased people, as commonly reported in modern NDEs (e.g., Moody \& Perry, 1988, pp. 9-10), played a prominent role in the vision of Er, though none were identified as his own acquaintances. From the moment he retreated from his body, Er supposedly "journeyed with a great company," and the text makes it abundantly clear that what followed was a judgment of the souls of the dead and an insight into the peregrinations of disembodied souls in general. 
Next, Er was treated to an impression of the manner in which the souls of malefic people receive punishment upon death in a large hollow space called a stómion or 'mouth.' He was especially struck by the fate of one Ardiaeus:

Now this Ardiaeos had been tyrant in a certain city of Pamphylia just a thousand years before that time and had put to death his old father and his elder brother, and had done many other unholy deeds, as was the report. ... For indeed this was one of the dreadful sights we beheld; when we were near the mouth and about to issue forth and all our other sufferings were ended, we suddenly caught sight of him and of others, the most of them, I may say, tyrants. ... Ardiaeus and others they bound hand and foot and head and flung down and flayed them and dragged them by the wayside, carding them on thorns and signifying to those who from time to time passed by for what cause they were borne away, and that they were to be hurled into Tartarus. (Plato, 1946, pp. 497, 499)

This early depiction of 'hell' that was to develop into a rich literary genre exemplifies a minority subtype of NDE estimated to represent $0.3 \%$ of all NDEs and aptly labelled a "hellish" NDE, one "that contains extreme fear, panic, or anger and may also contain visions of demonic creatures" (Moody \& Perry, 1988, p. 20; see also Ring, 1980, pp. 44...45, 124, 192-195; Noyes \& Kletti, 1976, p. 110). Though Moody (1975, p. 97) originally dismissed this type of NDE, subsequent researchers have affirmed its occurrence (Greyson \& Bush, 1992; Zaleski, 1987, p. 7, cf. 188). According to van Lommel (2007, pp. 52, 55), the passage through the dark tunnel is a frightening experience for approximately $15 \%$ of near-death experiencers (NDErs), whereas possibly $1-2 \%$ remain in this oppressive state, or progress into an even more frightening one, for the duration of the NDE. In one particularly graphic case (Moody \& Perry, 1988), "a man reported that he was ushered into hell by mistake," reporting:

I went downstairs! Downstairs was dark, people were howling, [there was] fire, they wanted a drink of water ... It was not a tunnel, more than a tunnel, a great big one. I was floating down ... I seen [sic] a lot of people down there, screaming, howling ... No clothes at all. ... I'd say about, almost a million to me. ... They were miserable and hateful. (p. 20; see also p. 118)

As another example, one of van Lommel's patients (2007) recalled:

I suddenly stopped in this dark tunnel and began to fall down at an enormous speed, faster and faster and faster. As if I was literally hurled down vertically, with my head downwards, into this black 
hole. It was so pitch-black, I couldn't see my hand in front of my face. And while I was falling like that, I began to hear screaming, shrieks, heart-rending, horrible, horrible laughter and the most revolting stench you can imagine, and then the black environment changed into fire ... And there were all sorts of terrible-looking and frightening creatures, the one even scarier than the other, that reached for me.... I begged God for help ... And all of a sudden I was woken up by voices of female doctors at the First Aid Department, who had reanimated me .... (p. 55)

Sixth, a fast review of one's own life, as is often found in modern reports of NDEs, is not found in Plato's exposition. However, it is reasonable to suspect a closely related theme in the portrayal of the judgment of the souls, during which every single deed in the lives of these beings was scrutinised; Er "saw, by each opening of heaven and earth, the souls departing after judgment had been passed upon them" (Plato, 1946, p. 493). In modern accounts of this 'life review,' experiencers often express a sentiment of complete exposure combined with a profound sense of being morally judged. For example, one of van Lommel's (2007) patients revealed:

My entire existence up until now seemed to be placed in front of me in
a sort of panoramic, three-dimensional flashback, and each event
seemed to be coupled with an awareness of good or bad or with an
insight in its cause or consequences. I did not just constantly witness
everything from my own perspective: I also knew the thoughts of
everyone who had been associated with the event, as if they had their
thoughts within me. In this way I got to see not just what I had done
or thought, but even how that had affected others, as if I was
watching with omniscient eyes. ... In retrospect, I cannot say how
long this life review and insight of my life lasted; it may have been
long, for all subjects were dealt with, yet at the same time it seemed
just a fraction of a second, as I observed everything at once. (p. 60)

Clearly, the life review is not an impassionate recollection of one's life but comes with a participatory form of ethical judgment; experiencers "can ... witness their 'rights' and 'wrongs' with crystal clarity" (Morse \& Perry, 1988, p. 37), and throughout the experience, "the Being is with those people, asking them what good they have done with their lives" (p. 11). Perhaps the judgment of each soul in front of a tribunal, as Er witnessed, corresponds to the experience of a "life review' in the presence of one or more beings of light. In his paraphrase of the myth of Er, Moody (1975) implicitly compared the judgment episode to the 'life review' known from NDEs: "The other souls were stopped and judged by divine beings, who could see at a 
glance, in some sort of display, all the things that the soul had done while in its earthly life" (p. 118). Zaleski (1987) observed that "it is easy to recognize an affinity between the panoramic life review and the various forms of encounter with deeds in medieval vision literature" (p. 27; see also p. 129). The emotional process of having to come to terms with the harm one has inflicted on others may be on a par with the 'punishments' handed out to the purged souls in Er's description. It should be borne in mind, though, that in the vision of $\mathrm{Er}$ these punishments are enforced subsequent to the judgment, whereas the remorse felt during a modern life review is instantaneous, wholly purifying, and not followed by added suffering. Another point of difference is that Er witnessed rather than experienced this scene personally. And whereas the scene of judgment in Plato's text is harsh, the experience tends to be gentle in modern cases:

Even when someone was aware of a presence or voice and interpreted it as a 'being' external to himself, there was no sense of being judged by it. Instead, love, comfort, and acceptance tended to be felt; that was the emotional context in which a self-assessment was often made" (Ring, 1980, p. 196).

Finally, the experiencer is often confronted with a boundary or limit, the passage of which would mark a permanent departure from the world of the living, which is not yet permitted because of a remaining task or duty to be fulfilled on earth (Moody, 1975, p. 73; van Lommel, 2007, p. 63). A clear example of this motif is the following fragment of a modern NDE:

I felt that I let go of my body and began to ascend. Through the roof. Over the hospital. Everything became smaller and the speed increased dramatically. ... Above me, I saw a bright light and on the way towards it I heard wonderful music and I saw colors that I had never observed before. Apart from the feelings I just described, I also had a feeling that this was a completely different dimension. If anything was not found there, it was our earthly concept of time! And I had a kind of expanded vision on that other dimension. On my way upward, towards that all-embracing light, I saw countless other 'beings' that were also on their ways. When I nearly arrived at that light, I was stopped by a kind of fleece behind which the light was situated. (van Lommel, 2007, p. 54)

The equivalent of this liminal zone in Plato's account are the two juxtaposed apertures where souls receive judgment for their deeds. In a fashion typical of modern NDEs (Moody \& Perry, 1988, pp. 12-13; Zaleski, 1987, p. 33), Er is denied access, despite his protestations, and 
is appointed as a 'messenger' who must convey the posthumous fate of souls to other mortals: "When he himself drew near they told him that he must be the messenger to mankind to tell them of that other world, and they charged him to give ear and to observe everything in the place" (Plato, 1946, pp. 493, 495). The information Er was to convey to the living amounted to a type of supreme and otherwise inaccessible 'wisdom' that can be structurally compared to the trait of 'access to universal knowledge' in the modern paradigm of NDEs. The judges that thus instructed Er and bestowed the necessary knowledge on him typologically correspond to the 'being of light' known from NDEs, but this is no more than speculation and ought not to be included in Er's count of traits of NDEs.

Summing up, the vision of Er emerges as a convincing case of an NDE. At least eight out of the list of 16 core elements can be conclusively identified in the story of Er: OBE; passage towards a bright light; observation of an otherworldly, beautiful landscape; 'hellish' experience; encounter with deceased people; life review (judgment); experience of a boundary; and forced return. Not attested are: difficulty to describe what has been seen; awareness of being dead; sound upon OBE; absence of pain; encounter with a being of light or a guide; flash forward; conscious return to the body; changed lifestyle. Bremmer's (2002) principal objection that "Er ... leaves the body but does not even know how he returned" (p. 92) is countered with the observation that the 'sudden return' is actually a trademark of the NDE: On "the mode of return to physical life and of why the return took place,"

most say simply that they do not know how or why they returned, or that they can only make guesses. A few very definitely feel that their own decisions to get back to the body and to return to earthly life were the operative factors. (Moody, 1975, p. 79; see also van Lommel, 2007, p. 64)

On these grounds, the original impression that the vision of Er constitutes a genuine NDE is rehabilitated.

\section{The Vision of Thespesius as a Near-Death Experience}

Plutarch's rendition of the vision of Thespesius is considerably longer than Plato's report of Er. The intimation that, for Thespesius, "nothing that he saw was familiar" upon the detachment of his 
"intelligence" from his body (Plutarch, 1984, p. 273) illustrates Moody's motif of the difficulty NDErs experience in describing what they have seen.

Second, the sensation of being withdrawn from one's body is vividly captured in Plutarch's words:

He said that when his intelligence was driven from his body, the change made him feel as a pilot might at first on being flung into the depths of the sea; his next impression was that he had risen somewhat and was breathing with his whole being and seeing on all sides, his soul having opened wide as if it were a single eye. (p. 273)

The impression of a slight elevation coupled with a vision of $360^{\circ}$ is familiar from contemporary reports of NDEs, in which a patient who is clinically dead or in coma, often during surgery or resuscitation, ascends towards the ceiling and watches one's dead body and the operating team of doctors from that position.

Third, like Er, Thespesius is not explicit concerning encapsulation in a dark 'tunnel,' but a hint to his involuntary and unnerving passage through a dark medium may be detected in the comparison of his 'liberated' soul to a kybernétēs - a "pilot” or 'sailor' - who is hurled ek ploiou ... eis bythòn, 'from the ship ... into the depths' of the sea, implying an initial surrender to a 'bottomless' pit of darkness. The entire first part of Thespesius's itinerary, during which he observed countless other souls, may have transpired in this relatively dark realm. An equally likely counterpart to the rapid passage of a modern NDEr towards a place of scintillating light is the ensuing episode during which Thespesius is "swiftly taken by the guide over what appeared an immense distance, traversing it easily and unerringly, buoyed up by the beams of the light as by wings, until he came to a great chasm" (Plutarch, 1984, p. 285).

As a fourth parallel, Thespesius then arrived in a place that compares to the wondrous landscape of almost magical beauty, typically qualified as colorful and replete with exquisite flowers, music, and smells, that is found in modern NDEs. For Thespesius, this region constituted the interior of chásma méga kaì kátō diēkon, a "great chasm extending all the way down" that "was called the place of Lethe:"

Within, it had the appearance of a Bacchic grotto: It was gaily diversified with tender leafage and all the hues of flowers. From it was wafted a soft and gentle breeze that carried up fragrant scents, 
arousing wondrous pleasures and such a mood as wine induces in those who are becoming tipsy; for as the souls regaled themselves on the sweet odors they grew expansive and friendly with one another; and the place all about was full of bacchic revelry and laughter and the various strains of festivity and merry-making. (Plutarch, 1984, pp. 285, 287)

The presence of throngs of discarnate souls in this chasm and the one described further on identifies these regions as the 'underworld,' resonant with Hesiod's (2006, pp. 62-63) earlier description of Tartarus as a chásma még' or "great chasm," as well as the gaping 'mouth' perceived by Er.

Among these masses, Thespesius, like Er, claimed to have witnessed scenes of infernal torment that really formed the raison d'etre for inclusion of the entire vision into Plutarch's (1984) treatise on The Divine Vengeance:

They now turned to view those who were suffering punishment. At first these presented only a disagreeable and piteous spectacle; but ... Thespesius kept meeting friends, kinsmen, and comrades who were being punished, a thing he never would have looked for, and these lamented to him and raised a cry of wailing as they underwent fearful torments and ignominious and excruciating chastisements .... (Plutarch, 1984, p. 293)

The motif of 'hell,' which is elaborated at great length, appears to warrant a legitimate fifth score on the chart of elements of an NDE.

In corroboration of a sixth familiar element in modern NDEs, Thespesius discerned other souls, radiant to different degrees, that inhabited both the marvellous landscape and the 'Inferno.' These were depicted as "human in form, but slight in bulk" and "enveloped all around with light and translucent within, although not all to the same degree" (Plutarch, 1984, pp. 275, 277). This description accords well with NDErs in recent times who "say that the spiritual body has shape and form unlike our physical bodies. It has arms and a shape although most are at a loss to describe what it looks like. Some people describe it as a cloud of colors ..." (Moody \& Perry, 1988, p. 8; see also Zaleski, 1987, pp. 50-51). In the course of his extra-corporeal adventure, Thespesius recognized some relatives and friends among these souls:

Most of the souls indeed he failed to recognize, but seeing two or three of his acquaintance, he endeavoured to join them and speak to them. These, however, would not hear him and were not in their right mind, but in their frenzy and panic avoiding all sight and contact, they at first strayed about singly; later, meeting many others in the same 
condition, they clung to them and moved about indistinguishably in all manner of aimless motions and uttered inarticulate sounds, mingled with outcries as of lamentation and terror. (Plutarch, 1984, p. 275)

Also among the souls that received torture,

Thespesius kept meeting friends, kinsmen, and comrades who were being punished ... and when he at last caught sight of his own father emerging from a pit, covered with brands and scars, stretching out his arms to him, and not allowed by those in charge of the punishments to keep silent, ... Thespesius in his consternation and terror did not dare to resort to supplication or intercede for his father .... (Plutarch, 1984, p. 293)

But not all souls suffered such distress. Among a company of happier souls, the protagonist communicated with another family member who clarified that Thespesius was not yet destined to die:

Other souls, above, in a pure region of the ambient, were joyful in aspect and out of friendliness often approached one another, but shunned the other, tumultuous souls, indicating their distaste, he said, by contracting into themselves, but their delight and welcome by expansion and diffusion. Here, he said, he recognized one soul, that of a kinsman, though not distinctly, as he was but a child when the kinsman died; but it drew near and said: "Greetings, Thespesius." He was taken aback and said he was not Thespesius but Aridaeus. "You were that before," was the reply, "but henceforth you are Thespesius. For you must further know you are not dead, but through a divine dispensation are present here in your intelligence, having left the rest of your soul, like an anchor, behind in your body. Now and hereafter know it by this token: The souls of the dead neither cast a shadow nor blink their eyes." At this Thespesius, by an effort of thought, became more collected, and looking steadily, saw a certain faint and shadowy line floating along with him, while the rest were enveloped all around with light and translucent within, although not all to the same degree. (Plutarch, 1984, pp. 275, 277)

As the words of the kinsman expose Thespesius's conviction that he was genuinely dead, evidence is given that the motif of awareness of being dead, common with NDEs, likewise applies to Thespesius's case.

An eighth recurrent feature of NDEs is the perception of an aweinspiring radiant light or being of light, with which the 'deceased' traveller is not yet allowed to engage fully (Moody \& Perry, 1988, pp. 10-11). Having shown Thespesius the two chasms, the infernal guide discourses on the cult of Apollo, the sun god, a subject in which Plutarch, as a priest of Apollo at Delphi, naturally took a deep interest. 
As Plutarch (1984) quite clearly situated this scene "at the confines of the sublunary region, where the atmosphere of air gives way to one of fire or aether" (pp. 289, 291), and Thespesius found himself in the orbital path of the moon, the relevance of this speech is manifestly that Thespesius at this point gazes at the brilliant lustre of the sun and the metaphysical tripod on which it rests, but, despite the guide's best efforts, is not permitted to proceed:

"As for Apollo's oracle," he said, "I hardly know whether you will be able to catch sight of it; for the cable of your soul gives no further upward play and does not grow slack, but holds taut, being made fast to the body." At the same time he endeavored to draw Thespesius near and show him the light that came (he said) from the tripod, and passing through the bosom of Themis [the divine mistress of the oracle before Apollo, see Lucan, Pharsalia, 5. 81), rested on Parnassus, but it was so bright that Thespesius, for all his eagerness, did not see it. (pp. 289, 291)

Thespesius's glance at the majestic sun god thus counts as a possible equivalent to the glimpse of a radiant being in modern NDEs; Apollo clearly serves here as the ancient Greek equivalent of 'God,' 'Allah,' 'Buddha,' 'Yama,' or other expressions for the most exalted being in modern reports with a religious varnish. The implication that the light was too bright for Thespesius to endure is at odds with the observations of modern people for whom the radiance of the "being of light' "does not in any way hurt their eyes, or dazzle them ..." (Moody, 1975, p. 58; see also Moody \& Perry, 1988, p. 10; van Lommel, 2007, p. 58). However, cases can occasionally be found in which the NDEr can hardly endure the light; in Ring's (1980) sample, for instance, "one respondent implied that the illumination hurt his eyes. All others denied that this was the case - usually emphatically" (p. 287, note 11).

As a ninth match with a modest number of modern reports (Moody, 1975, p. 101; Moody \& Perry, 1988, p. 22; Ring, 1980, p. 67; van Lommel, 2007, p. 62), Thespesius is at this point granted a quick 'flash forward' into the future, which even includes some information about his own fate:

But he did hear, as he passed by, a woman's high voice foretelling in verse among other things the time (it appears) of his own death. The voice was the Sibyl's, the daemon said, who sang of the future as she was carried about on the face of the moon. He accordingly desired to hear more, but was thrust back, as in an eddy, by the onrush of the moon, and caught but little. Among this was a prophecy about Mt. Vesuvius and the surge of flame that would pass over Dicaearcheia, 
and a fragment of verse about the emperor of those days: / ... good, he will through sickness leave the throne. (Plutarch, 1984, p. 291)

Thespesius's inability to approach Apollo, constrained by the cable that still tied him to his physical body and disturbed by the rushing moon, marks the familiar motif of an impassable, final threshold found in reports of NDEs. This element constitutes a tenth match.

Plutarch's (1984) exposition does not contain a clear-cut example of a 'life review' as known from modern reports of NDEs, However, as in the case of Er, an equivalent motif can be perceived in the judgment passed on individual souls by one or more 'beings of light.' Strongly reminiscent of the life review is the description Thespesius's guide gave of the treatment meted out to malicious souls by one of the Fates:

But whoever comes here from the world below unpunished and unpurged, is fastened upon by Dikê, exposed to view and naked in his soul, having nothing in which to sink out of sight and hide himself and cloak his baseness, but on all sides plainly visible to all in all his shame. In this state she first shows him to his good parents and ancestors - if such they are - as one execrable and unworthy of them .... (p. 281)

As a twelfth point of agreement with the typical elements listed for modern NDEs, Thespesius claimed to have undergone a conscious and fairly sudden return to this body: While observing how some souls were prepared for a new birth, a "woman interposed, and he was suddenly pulled away as by a cord and cast in a strong and violent gust of wind upon his body, opening his eyes again almost from his very grave" (Plutarch, 1984, p. 299). The notion that this return was forced and quite contrary to the desire of the experiencer, as commonly attested in association with modern NDEs, surfaces immediately after Thespesius has enjoyed the fabulous bliss of the 'place of Lethe,' for

although Thespesius wished to linger, the guide would not allow it, but pulled him away by main force, informing him as he did so that the intelligent part of the soul is dissolved away and liquefied by pleasure, while the irrational and carnal part is fed by its flow and puts on flesh and thus induces memory of the body .... (p. 287)

Last but not least, the drastic changes this experience effected on Thespesius's life bring to mind the typically life-altering nature of modern NDEs. Plutarch's narration of the story opens with a comment on the deplorable state of Thespesius's life prior to his accident: This

man of Soli ... had spent his early life in great dissipation, and then, soon running through his estate, had for some time practised a 
further villainy brought on by his straitened circumstances. ... Abstaining, then, from no shameful act conducive to gratification or gain, he accumulated no very considerable fortune, but in a brief space a prodigious reputation for knavery. (Plutarch, 1984, pp. 269, 271)

After his temporary death,

recovering his strength and senses, he instituted a change in his way of life that could hardly be believed; for the Cilicians know of no one in those times more honest in his engagements, more pious toward heaven, or more grievous to his enemies and faithful to his friends; so that all who met him longed to hear the reason for the difference, supposing nothing ordinary could have caused so great a reformation in character. (pp. 271, 273)

On this analysis, the vision of Thespesius scores an impressive 14 out of the 16 core elements listed above: difficulty to describe what has been seen; awareness of being dead; OBE; passage towards a bright light; observation of an otherworldly, beautiful landscape; 'hellish' experience; encounter with deceased people, including relatives or friends; encounter with a being of light or a guide; life review (judgment); flash forward; experience of a boundary; a forced return; conscious return to the body; changed lifestyle. Not attested are two features: sound upon OBE and absence of pain. This result stands in stark contrast to Bremmer's (2002) ungenerous verdict, cited earlier, that "regarding the typical NDE details, we find only the feeling of drifting upwards and the recognition of some of his former acquaintances" (p. 94). Bremmer's evasive disclaimer that "in a way, these details are not very specific" (p. 94) is misplaced insofar as such elements need not be "very specific" at all in order to qualify as veritable aspects of an NDE. Besides, in the same breath Bremmer had also dismissed the vision of Er for an exuberance of detail, exposing a whimsical method of reasoning. Far from a grudging attempt to dispute this assertion, a careful examination of the tale of Thespesius should inspire the conclusion that the story contains a remarkably detailed and coherent report of an NDE. Indeed, it may well have been Plutarch's familiarity with this story that colored his understanding of the posthumous fate of the soul in terms redolent of an NDE, as expressed in another one of his works:

In the beginning there is straying and wandering, the weariness of running this way and that, and nervous journeys through darkness that reach no goal, and then immediately before the consummation every possible terror, shivering and trembling and sweating and 
amazement. But after this a marvelous light meets the wanderer, and open country and meadow lands welcome him; and in that place there are voices and dancing and the solemn majesty of sacred music and holy visions. And amidst these, he walks at large in new freedom, now perfect and fully initiated ... (Plutarch, 1969, pp. 317, 319; see also Burkert, 1987, p. 91; Mead, 1907, pp. 44, 73; Plato, Phaedrus, 29 (249D); and Platthy, 1992, p. 54; for the connection with mystery initiations.)

Concerning Er, as previously stated, Bremmer (2002) had argued that "the incredible, dramatic details of Er's survival surely should read as a warning to the reader of the fictional character of the account, not as an attempt to provide an eye witness report" (p. 90). Instead, I propose exactly the opposite argument: An elaborate description rich in detail is indeed typical of NDE reports, and it is hardly conceivable that someone who has not personally gone through an NDE could have conjured up such a strikingly typical account, using fancy, imagination, or literary input alone. If it must be conceded, then, that at least someone's genuine NDE has informed the respective visions of $\mathrm{Er}$ and Thespesius, one wonders why these people could not simply have been the selfsame characters tradition has fingered in this capacity: two people named $\mathrm{Er}$ of Pamphylia and Thespesius of Soli. De Lacy and Einarson's assertion that "Thespesius ... is doubtless a fiction of Plutarch's" (Plutarch, 1984, p. 173) can hardly be maintained solely on the basis that the historicity of this character cannot be proven or that his name "was chosen for its meaning, thespesios being often used of things divine and strange".

\section{Other Weaknesses in Bremmer's Assessment}

Other aspects of Bremmer's discussion give the impression that it was written rather hastily, sprinkled with a number of facile observations and suffering from insufficient preparatory reading. For example, Bremmer (2002) regarded the perceived transition of the escaping soul through a 'tunnel' as "typically modern:" "How many people in earlier periods would have known of a tunnel?" (p. 101). The term "modern" is expediently vague in this argument. Hieronymus Bosch's famous painting entitled the Ascent of the Blessed or the Ascent into the Empyrean (1490-1516 CE), which is currently in the Palazzo Ducale, Venice, depicts a number of winged angels lifting up 
human bodies from the clouds through a tunnel that appears dark at its lower end and radiant at its distant extremity - as noted also by Moody and Perry (1988, p. 9). Even if one would go so far as to brand Bosch's iconography modern, 'caves,' 'chasms,' and 'hollow tubes' such as the ones featured in the passages from Plato and Plutarch reviewed above are credible counterparts to such tunnels, proving that the motif, if defined in a more generous sense, is as ancient as the NDE per se. As variations on the tunnel motif, Zaleski (1987) listed "walking through immense calverts or pipes, spinning in vertiginous spirals, descending into caves or wells" and "a dark valley or narrow path to a realm of light” (p. 122). Kellehear's (2008, pp. 251, 255-257, 261) overview of near-death experiences from non-Western cultures lacks unambiguous examples of tunnels but does list cases of movement through narrow, dark, and longitudinal channels such as a "dark tubular calyx" or along a road. As an example of a "great glen" with a striking longitudinal aspect, the Irish visionary Laisrén, presumably the abbot of Lethglenn, Carlow ( $\uparrow 638 \mathrm{CE}$ ), found his soul passing through "a great glen. It seemed as long to him as if he saw from the rising of the sun to its setting" (Meyer, 1899, pp. 117-118).

In his discussion of modern NDEs, Bremmer (2002) further distinguished between "relatives or close friends" and "a being of light, who is often not identified" (p. 101) as two classes of entities that the vagrant soul may encounter. Of the latter, Bremmer contended that this radiant being no longer acts as a 'psychopomp' or guide to the soul, as it used to do in reports from antiquity. The explanation he proposed for this change is that "modern man [sic] travels by himself and no longer needs supernatural help" (p. 101). An intuitive response to this cavalier solution to a perhaps non-existent problem is that 'guided tours' are just as much alive today as ever, while solitary travellers have existed in all ages. That point aside, the distinction between an 'angelic' or divine being and a lost relative is not rigid but almost evaporates upon a closer examination as the two merge into a single category of a spiritual 'companion,' either luminous or auditory, whose identity the wandering soul may or may not recognize. Ring (1980), for example, suggested that meetings with "ordinary spirits" and with what he designated the "presence" tend to be

an either/or feature of the experience: Either one sees relatives or one encounters a presence, but not both. ... If the presence doesn't manifest itself or if the individual doesn't himself choose to return to life, the spirits tend to appear to send him back. (pp. 190-191, see also p. 68 \& p. 288 , note 4$)$ 
In either role, the transcendental attendant often acts as a guide, in past as well as present accounts. Thus, Thespesius did not communicate with the 'presence' or the 'being of light' but with a "kinsman" serving as an infernal guide. And in some modern reports, the soul is received and accompanied by a being of light or a deceased relative whom the NDEr clearly portrays as an attending guide, proving Bremmer's initial observation plain wrong (for example, Zaleski, 1987, pp. 126, 188). Moody and Perry (1988) interviewed a woman who, during an NDE in 1971, "met a guide who took her through a life review and gave her information about the future" (p. 22). A child experienced the presence of two guides: "When I was going up in the tunnel two people were helping me. I saw them as they got out into the light. They were with me the whole way" (p. 50). And in Monique Hennequin's detailed description of the NDE she had after her second Caesarian section at the age of 31 years, her father acted as a guide of sorts who coaxed her to return into her body:

Like a giant shadow, my father suddenly drifted around the corner. He did not look backward or forward. He moved forward with stately strides. I sensed that he knew his way in this darkness. His feet did not touch anything, as if he walked or floated in 'slow motion' and nevertheless he steadily went forth in front of me at an enormous speed. I desired to see him, his face, his countenance. Whatever I tried, he kept moving and never turned his face towards me for a second. I was so eager to see him, touch him, query him, almost beg him as to what I should do. Follow behind him or move in another direction. In a way, I felt that if any contact were established, I would be completely unable to return. ... There was a reason why he failed to look at me. There was a reason why he did not hold on to me. He had come solely to clarify everything here for me. It felt like his final 'duty' as educator, before he could proceed towards that light. Everything now had to become clear to me. And, again, it would have to be my own decision. If I wanted, he would accompany me to the point of light ... Judging by my father's attitude I felt that he did not want me to accompany him. I loved him, even here with this attitude. All of a sudden I felt what he felt, I knew what he knew. He made this moment clear in a single blow, including what I ought to do. This was not my 'end station,' this was his world now, this was his (and temporarily my) sphere and it was his floor and his light there in the distance. I had to go back and fully of my own accord. ... I scrupulously kept running behind him (without legs, of course). There was no way I could catch up with him. I tried to yell, cry, beg, but nothing reached him. I felt the pain in him. The pain that he could not embrace me and help me to decide. I tried to stand still, screaming, like a little child in the supermarket, hoping that he would halt in order to help me. He kept moving towards the light that approached 
ever closer. Now I really had to make a decision, the end (or the beginning of his light) came near. I could almost touch him now. Almost ... Right before my eyes, he entered the overwhelming light. (van Lommel, 2007, pp. 201-202)

Despite his stoical and incommunicative attitude, the father nevertheless served as a guide leading Monique very close to the ultimate source of light. The seeming rudeness or sudden vanishing of the infernal psychopomp is a fixture of the story of Thespesius as well, for just after Thespesius had caught a glimpse of the future and had been presented with a scene of torture, "wishing to turn back and escape," he "saw no longer that kindly kinsman who had been his guide ..." (Plutarch, 1984, p. 293).

A third implausible suggestion Bremmer (2002) made is the idea that the life review is a recent phenomenon:

Can it be that the relatively late appearance of reports of the life film have something to do with the development of the diorama and its reinforcement by the train in the nineteenth century, which enabled people to see a fast succession of scenes as they had never been able to do before? (p. 102)

This idea can be ratified to the extent that the literal usage of words such as 'review,' 'film,' or 'movie' will only have sprung into existence with the invention of film, yet what witnesses actually experienced is much older and used to be conveyed through different metaphors: "For the traditional book or mirror of deeds, near-death visions provide plausible substitutes: a slide show, movie, or, for the more technically advanced, a hologram" (Zaleski, 1987, p. 129). Any impression that the phenomenon itself is recent is quickly dispelled by the observation that some people, in experiencing their life review, "recall no awareness of temporal order at all. The remembrance was instantaneous; everything appeared at once, and they could take it all in with one mental glance" (Moody, 1975, pp. 64-65; see also Moody \& Perry, 1988, p. 11). "These images usually appear in no definite sequence (though they sometimes do), but rather as a simultaneous matrix of impressions, like a hologram" (Ring, 1980, p. 67). One of the people whom Moody (1975) interviewed recalled:

After all this banging and going through this long, dark place, all of my childhood thoughts, my whole entire life was there at the end of this tunnel, just flashing in front of me. It was not exactly in terms of pictures, more in the form of thought, I guess. I can't exactly describe it to you, but it was just all there. It was just all there at once, I mean, 
not one thing at a time, blinking off and on, but it was everything, everything at one time. (p. 69; see also p. 73)

Clearly, a cinematic succession of images is hardly what is being conveyed in experiences of this type, and wherever terms such as 'film' or 'review' are used, the metaphor is no more than a flawed approximation of the actual experience. To clinch the matter, a life review was also described in the mystical writings of the Swedish polymath, Emanuel Swedenborg (1749/1928), who died more than a century before the invention of the motion picture camera:

The memory of all these things the man has with him when he comes into the other life, and he is successively brought into full recollection of them. This is his Book of Life, which is opened in the other life, and according to which he is judged. ... All the ends, which to him have been in obscurity, and all the things he has thought; together with everything that from these he has spoken and done, down to the smallest point, are in that Book, that is, in the interior memory, and whenever the Lord grants, are made manifest before the angels as in clear day. This has several times been shown me, and has been attested by so much experience that not the least doubt remains. (p. 238)

Long before that, the $14^{\text {th }}$ century CE Tibetan text Bar-do Thos-grol Chen-mo or The Great Liberation by Hearing in the Intermediate States (The Tibetan book of the dead, 2006), mediated by Karma Lingpa and detailing the post-mortal fate of the soul, described the moment when "the harsh and bewildering experiences related to past actions have arisen" (p. 232) and the soul is "under the sway of negative past actions" (p. 237; see also p. 234). Centuries earlier again, around $250 \mathrm{CE}$, according to the long Latin version of the Vision of Saint Paul or the Apocalypse of Paul (Anonymous, 1965, p. 767), an angel asked Paul: "Have you believed and understood that whatever each of you has done, he sees it in the hour of his need?" As suggested earlier, though no example of an actual life review has to date been discovered in classical literature, the motif is probably comparable to the judgment of all one's deeds in front of a celestial judge, on which occasion - according to Plutarch's wording - nothing would be hidden and one's deepest intentions would be exposed to all and sundry. In the course of this process, the experiencer obviously goes through the details of one's entire life 'in a flash,' comparable to NDErs who have experienced a life review. The confrontational aspect of the life review appears to match the punishments and disfigurements inflicted on these souls in Plutarch's story. 
Finally, Bremmer (2002) advanced the following explanation for the apparent dearth of NDEs in ancient literature:

It is rather remarkable, then, that pagan antiquity has given us so few literary accounts of a soul visiting the hereafter. This scarcity of description attests to a paucity of interest in the afterlife, and this is perhaps confirmed by the relative lack of epitaphs speaking about the afterworld. (p. 95)

Here again, one is hard-pressed to accept Bremmer's conclusion. Far from demonstrating a lack of interest in the hereafter in antiquity, which is an indefensible claim anyway, it is easy to think of reasonable explanations for the rarity of ancient reports of NDEs. Due to the climate, Mediterranean cultures tended to bury their dead very quickly, often overnight, thus preventing comatose people who could have recovered within a few days from surviving and relating their stories. More significantly, the main reason why so many NDEs can be heard today is, of course, that the methods for reanimation of clinically dead people and for otherwise restoring to health critically ill people have improved so dramatically. Thanks to the development of cardiopulmonary resuscitation, such as the introduction of defibrillators in the mid- $20^{\text {th }}$ century, many more people survive heart attacks today than would have been possible in earlier times. In 1975, Moody made exactly this point:

I strongly suspect that near-death experiences have been vastly more common in the past few decades than in earlier periods. The reason for this is simply that it has only been in fairly recent times that advanced resuscitation technology has been available. Many of the people who have been brought back in our era would not have survived in earlier years. Injections of adrenaline into the heart, a machine which delivers a shock to the heart, and artificial heart and lung machines are examples of such medical advances. (p. 145; see also Moody \& Perry, 1988, p. 80)

From this point of view, it appears to be very fortunate to have even the few extant reports from antiquity at our disposal.

In conclusion, the respective visions of Er and Thespesius emerge as genuine accounts of NDEs. From what I have discerned, the former actually constitutes the oldest known direct such account on record.

\section{The Vision of Timarchus as a Near-Death Experience}

In addition to actually being or believing oneself to be near death, extreme isolation combined with fasting and deep meditation may 
induce a state of mind analogous to an NDE (Moody, 1975, pp. 170175; van Lommel, 2007, pp. 106, 285-286, 316). In other words, a stroke, a heart attack, or an accident is not always required to trigger such an experience. A possible example of an NDE through isolation, not considered by Bremmer (2002), is the case of Timarchus of Chaeronea, a young student of Socrates, whose story Plutarch (1984, pp. 458-477), a later resident of Chaeronea, narrated by mouth of Simmias of Thebes $\left(5^{\text {th }}-4^{\text {th }}\right.$ century BCE), another follower of Socrates. Jeno Platthy (1992, pp. 80-83) appears to be the only writer to have recognized Timarchus's tale as an NDE, but he did not discuss it at any length.

According to Simmias's report, Timarchus provoked his vision by descending "into the crypt of Trophonius" and remaining "underground two nights and a day" (Plutarch, 1984, p. 461), as De Lacy and Einarson noted was the custom at this sanctuary in Lebadeia, Boeotia (pp. 460-461, note a). After this time,

most people had already given up hope, and his family were lamenting him for dead, when he came up in the morning with a radiant countenance. He did obeisance to the god, and as soon as he had escaped the crowd, began to tell us of many wonders seen and heard. (p. 461)

The liberation of Timarchus's soul from his body is related as follows:

He said that on descending into the oracular crypt his first experience was of profound darkness; next, after a prayer, he lay a long time not clearly aware whether he was awake or dreaming. It did seem to him, however, that at the same moment he heard a crash and was struck on the head, and that the sutures parted and released his soul. As it withdrew and mingled joyfully with air that was translucent and pure, it felt in the first place that now, after long being cramped, it had again found relief, and was growing larger than before, spreading out like a sail; and next that it faintly caught the whir of something revolving overhead with a pleasant sound. (p. 461)

This account might not be remarkable and might, indeed, be fictional, were it not for Simmias's reference to the various sounds Timarchus allegedly heard upon his departure. The initial psóphos or "crash," followed by a pleasant rhoizos or "whir of something revolving overhead," correspond to the occasional perception of a humming, buzzing, or whistling sound or a loud click in reports of modern NDEs, precisely at the moment a patient feels the sensation of being drawn out of one's body: 
In many cases, various unusual auditory sensations are reported to occur at or near death. Sometimes these are extremely unpleasant. A man who 'died' for twenty minutes during an abdominal operation describes 'a really bad buzzing noise coming from inside my head. It made me very uncomfortable. ... I'll never forget that noise.' Another woman tells how as she lost consciousness she heard 'a loud ringing. It could be described as a buzzing. And I was in a sort of whirling state.' I have also heard this annoying sensation described as a loud click, a roaring, a banging, and as a 'whistling sound, like the wind'. ... Often concurrently with the occurrence of the noise, people have the sensation of being pulled very rapidly through a dark space of some kind. (Moody, 1975, pp. 29-30; see also Ring, 1980, p. 95; van Lommel, 2007, p. 45).

Furthermore, Timarchus purported to have glanced into a domain that fits a description of the underworld:

Looking down he saw a great abyss, round, as though a sphere had been cut away; most terrible and deep it was, and filled with a mass of darkness that did not remain at rest, but was agitated and often welled up. From it could be heard innumerable roars and groans of animals, the wailing of innumerable babes, the mingled lamentations of men and women, and noise and uproar of every kind, coming faintly from far down in the depths, all of which startled him not a little. (Plutarch, 1984, p. 467)

The description of this hell as a deep chasm filled with the clamour of multitudes anticipates modern accounts of 'hellish' NDEs such as the ones cited earlier, whereas the dark chasm itself might represent the classic 'tunnel.' A few other familiar ingredients of an NDE can be detected in the story of Timarchus, but none are as elaborate as in the case of Thespesius.

Timarchus's identification of his head as the place where his soul exited and re-entered corresponds in modern literature to the "very few accounts" in which the return into the body is "recalled in some detail" and "re-entry is said to occur "through the head"' (Moody, 1975, p. 83; see also Zaleski, 1987, p. 118). One patient recalled how, upon returning into the body, the patient "entered it through what seemed to be the natural door, the former soft spot at the top of my head ..." (Zaleski, 1987, p. 139). Another NDEr remarked, perplexed, "I wouldn't hesitate to say that I think I [pause] I [pause] I entered my body through my head [questioning intonation]. But I don't know why that is" (Ring, 1980, p. 101).

Further, having marvelled at the fantastic scenery in which he arrived after the separation from his body, Timarchus was suddenly greeted by an entity that offered himself up as a guide: "After an 
interval, someone he did not see addressed him: 'Timarchus, what would you have me explain?' 'Everything,' he answered; 'for what is here that is not marvellous?"' (p. 467). In keeping with Ring's impression that an encounter with deceased relatives and one with an often invisible 'presence' are mutually exclusive, the disembodied voice Timarchus heard of tina ... ouch horómenon or "someone he did not see" (Plutarch, 1984, pp. 466-467) was not identified as a relative, as in the case of Thespesius, but did elucidate a good deal for Timarchus. It was also instrumental in allowing Timarchus a characteristic glimpse into the future, before forcing Timarchus's return, but the description is very parsimonious:

\begin{abstract}
"Of these matters," the voice said, "you will have better knowledge, young man, in the third month from now; for the present, depart." When the voice ceased Timarchus desired to turn (he said) and see who the speaker was. But once more he felt a sharp pain in his head, as though it had been violently compressed, and he lost all recognition and awareness of what was going on about him; but he presently recovered and saw that he was lying in the crypt of Trophonius near the entrance, at the very spot where he had first laid himself down. (pp. 475, 477)
\end{abstract}

The "sharp pain" Timarchus felt "in his head" upon his return, coupled with the "enjoyment" with which he had earlier viewed the spectacles of the other world, fit the general pattern of a painful return to physical existence following a perceived state of bliss. Although this description of Timarchus's experiences offers far less detail on traits of interest for NDE research, the whirring sound perceived upon the 'disembarkation' of the soul is a decisive argument for the authenticity of this account. In all, the story of Timarchus still scores seven out of 16 on the composite list of characteristic elements of an NDE: OBE; sound upon OBE; observation of an otherworldly, beautiful landscape; 'hellish' experience; encounter with a being of light or a guide; flash forward; and forced return. Not attested are: difficulty to describe what has been seen; awareness of being dead; absence of pain; passage towards a bright light; encounter with deceased people, often including relatives or friends; life review; experience of a boundary; conscious return to the body; and changed lifestyle.

\title{
'New' Motifs in Near-Death Experiences
}

If the visions of Er, Thespesius, and Timarchus are allowed as valid examples of NDEs, they may further be mined for additional insights 
into the nature and structure of NDEs in general, especially if parallels in the modern literature on the subject are available.

Plutarch (1984, pp. 272-273, 276-277) developed an elaborate nautical metaphor, according to which the dislodgement of Thespesius's phronoun or "intelligence" "made him feel as a pilot might at first on being flung into the depths of the sea" (p. 273), his 'intelligence' was "riding smoothly in the light like a ship on a calm sea" (p. 273), and he was told he had left "the rest of your soul, like an anchor, behind in your body" (p. 277). A vital part of the metaphor is the comparison of the elements of air and fire within which Thespesius journeyed to a 'sea.' Whereas the comparison of the soul or the cosmos to a vessel is a Pythagorean trope, it may ultimately root in NDEs involving 'water' as a suitable expression of the experience of floating in a different medium. An example is the following, modern account, from a nurse who nearly died in the process of giving birth:

At this time, I lost consciousness, and heard an annoying buzzing, ringing sound. The next thing I knew it seemed as if I were on a ship or a small vessel sailing to the other side of a large body of water. On the distant shore, I could see all of my loved ones who had died .... (Moody, 1975, p. 74)

The mythological Greek belief that the soul needs to cross an infernal river called Styx (see Homer, Odyssey, 10. 514; Hesiod, Theogony, 776; Socrates, apud Plato, Phaedo, 61 (113C); Virgil, Georgica, 1. 243; Aeneid, 6. 439) may reflect a similar motif.

As a second possible example of a 'new' element of NDEs, Plutarch in both texts employed the motif of a cable, rope, or thread tying the incorporeal soul to the unconscious body and thus preventing any further advances towards the benevolent light. Souls that were fully severed from their bodies lacked such a device:

At this Thespesius, by an effort of thought, became more collected, and looking steadily, saw a certain faint and shadowy line floating along with him, while the rest were enveloped all around with light and translucent within, although not all to the same degree. (Plutarch, 1984, p. 277)

Thespesius's wanderings were constrained by this grammé or 'line,' as "the cable of your soul gives no further upward play and does not grow slack, but holds taut, being made fast to the body" (Plutarch, 1984, pp. 290-291). Upon his return, "he was suddenly pulled away as by a cord" (p. 299), which must have been the same phenomenon. Resorting to marine imagery again, Timarchus's guide pointed out 
that each living human being is attached to its 'soul' or 'daemon' by means of a similar tie: "This is not dragged in with the rest, but is like a buoy attached to the top, floating on the surface in contact with the man's head, while he is as it were submerged in the depths ..." (p. 471). Timarchus further referred to this thread as a desmós or "tether," a sýndesmos or "tie," a chalinós or "bridle," and hēnía or 'reins' as implicit in the word euentiois. Is this motif reflected in any modern cases of an NDE?

The renowned psychoanalyst, Carl Jung, had an NDE in the wake of a heart attack suffered in a hospital in Switzerland in 1944 - at the age of 68 . His account, written some 30 years before Moody coined the term $N D E$, opened as follows:

At the beginning of 1944 I broke my foot, and this misadventure was followed by a heart attack. In a state of unconsciousness I experienced deliriums and visions which must have begun when I hung on the edge of death and was being given oxygen and camphor injections. The images were so tremendous that I myself concluded that I was close to death. ... I had reached the outermost limit, and do not know whether I was in a dream or an ecstasy. At any rate, extremely strange things began to happen to me. (Jung, 1963, p. 320)

Jung's return into the body, in "the 'box system" of the "threedimensional boxlike universe," felt to him as if he returned to a state of being "hung up in a box by a thread" (1963, p. 323). During the vision, he had also encountered the "image ... or, rather, his likeness," of the doctor who had treated him and appeared "framed by a golden chain" (1963, p. 322). Dismissing the unlikely possibility that Jung colored his own profound experience in this respect with a 'thread' from Plutarch's oeuvre, this parallel suggests that the attachment of the soul to a luminous string is another, though rare, element of an NDE (compare further Zaleski, 1987, pp. 53, 118-119, 234 note 34; Ring, 1980, pp. 225-226). Plutarch's material arguably offers the earliest known examples of this motif.

The perception of music, often of a soothing and a pleasing kind, is a third recurrent element in NDEs that has been noted quite regularly:

In other cases the auditory effects seem to take a more pleasant musical form. ... A young woman who nearly died from internal bleeding associated with a blood clotting disorder says that at the moment she collapsed, "I began to hear music of some sort, a majestic, really beautiful sort of music." (Moody, 1975, p. 30)

One person was treated to "wonderful music" during a close encounter with death: "Above me, I saw a bright light and on the 
way towards it I heard wonderful music and I saw colours that I had never observed before" (van Lommel, 2007, p. 54). At the age of 20 years, a $20^{\text {th }}$-century woman "found herself lost on a deserted country road one sub-zero night" and, while nearly freezing to death, heard celestial music she still recalled much later:

The pain was replaced by indescribable comfort and warmth of my innermost being. Then I heard magnificent music, not of this world but from unseen stars, creating a harmony of such rapturous beauty as to lift me to a transcendence of my being. The music is still audible in my mind, even after forty-seven years, it was of such beauty and harmony. (Noyes \& Kletti, 1976, p. 105)

A woman who nearly died as a result of a cerebral hemorrhage related: "There was music, very, very pleasant music. ... The music was beautiful" (\#17, in Ring, 1980, p. 62). A young man who tried to kill himself by taking an assortment of pills and, as a result, remained unconscious for four days had a comparable experience: "I also heard music - different music. ... It was usually like classical music; I like classical music. It wasn't exactly the music I've heard, but it was along that line. ... It made me relaxed. The fears went away when I listened to it" (\#99, in Ring, 1980, p. 122). A woman who "came to this experience as a result, apparently, of suffering cardiac failure at home, where, owing to some unusual circumstances, she lay comatose and undiscovered for three days," then, at a hospital, "had a cardiac arrest before eventually recovering," had memories of "a tremendous rushing sound," somewhat like "the sound of a tornado - a tremendous, gushing wind" and "very high-pitched," followed by music:

And I could hear beautiful music; I can't tell you what kind, because I never heard anything like it before. ... It sounds - I could describe it as a combination of vibrations, many vibrations. ... (How did that music make you feel?) Oooh, so good! The whole thing was just very good, very happy, very warm, very peaceful, very comforted, very I've never known that feeling in my whole life.” (\#20, in Ring, 1980, pp. 63,94$)$.

As a final example, a woman in her mid-thirties who had an NDE while undergoing surgery for a chronic intestinal disorder was reminded of ecclesiastical music: "And then I remember music.... It was kind of like church music, in a sense. Spiritual music" (\#7, in Ring, 1980, p. 36). In a poem, she expressed this as follows:

I went through a tunnel, at a very fast speed. 
I knew not what was happening,

But knew I'd soon be freed.

Then thru a door-like entity,

Into a valley of peace,

Where music played God's tune to me,

and made my fear release.

Colors bright, dancing lights,

Such a sight to see. (\#7, in Ring, 1980, p. 37)

Such reports of 'divine' music heard during NDEs compare favorably to the agreeable rhoizos or "whir of something revolving overhead" Timarchus's soul perceived after the initial psóphos or "crash": “...it faintly caught the whir of something revolving overhead with a pleasant sound" (Plutarch, 1984, pp. 460-461). Plutarch (1969), likewise, in his characterization of the posthumous fate of the soul, mused that "a marvellous light meets the wanderer, and open country and meadow lands welcome him; and in that place there are voices and dancing and the solemn majesty of sacred music and holy visions" ( $p$. 319). And Plato (1946) completed his description of the remarkable "straight light like a pillar" encountered by Er with the intimation that eight mellifluous tones produced mian harmonian or "a single harmony":

Up above on each of the rims of the circles a Siren stood, borne around in its revolution and uttering one sound, one note, and from all the eight there was the concord of a single harmony. And there were other three who sat round about at equal intervals, each one on her throne, the Fates, daughters of Necessity, clad in white vestments with filleted heads, Lachesis, and Clotho, and Atropos, who sang in unison with the music of the Sirens, Lachesis singing the things that were, Clotho the things that are, and Atropos the things that are to be. (pp. 503, 505)

\section{Conclusion}

In conclusion, the classical visions of three legendary people by the names of $\mathrm{Er}$ of Pamphylia, Aridaeus-Thespesius of Soli, and Timarchus of Chaeronea, as relayed in the writings of Plato and Plutarch, meet modern criteria sufficiently to qualify as credible examples of ancient NDEs. This result is significant, as it serves to augment the database of 'known' NDEs with regard to classical antiquity, an expansion back into time that is just as important as a geographic expansion of the dataset into other cultures. Indeed, the 
vision of Er must be treated as the oldest direct report of an NDE on record. In addition, the analysis of these accounts has yielded support for a number of additional traits sometimes associated with NDEs, which are too weak to count as independent diagnostic criteria but are worthy of investigation nonetheless. These include the use of the metaphor of water, the 'soul-cord,' and the perception of 'heavenly' music. The marked cosmological aspect of these three texts is a further ancillary trait to which an investigator can do justice only in a separate study.

\section{References*}

Anonymous. (1965). The apocalypse of Paul. (H. Duensing, Trans.). In W. Schneemelcher (Ed.), New testament apocrypha (vol. 2, pp. 755-798). Philadelphia, PA: Westminster Press.

Baal Shem Tov. (1972). In praise of the Baal Shem Tov [Shivhei ha-Besht]: The earliest collection of legends about the founder of Hasidism (D. Ben-Amos \& J. R. Mintz, Trans.). Bloomington, IN: Indiana University Press.

Bremmer, J. N. (2002). The rise and fall of the afterlife: The 1995 Read-Tuckwell Lectures at the University of Bristol. New York: Routledge.

Burkert, W. (1987). Ancient mystery cults. Cambridge, MA: Harvard University Press.

Greyson, B., \& Bush, N. E. (1992). Distressing near-death experiences. Psychiatry, 55, 95-110.

Hesiod. (2006). Hesiod: Theogony; Works and days; Testimonia. (G. W. Most, Trans.). Cambridge, MA: Harvard University Press.

Jung, C. G. (1963). Memories, dreams, reflections. (R. Winston \& C. Winston, Trans.). London: Collins.

Kellehear, A. (2008). Census of non-Western near-death experiences to 2005: Overview of the current data. Journal of Near-Death Studies, 26, 249-265.

Mead, G. R. S. (1907). The vision of Aridaeus (vol. III). London: Theosophical Publishing Society.

Meyer, K. (1899). Stories and songs from Irish Mss. In J. Sampson (Ed.), Otia Merseiana (vol. 1; pp. 113-128). New York: G. E. Stechert.

Moody, R. A. (1975). Life after life: The investigation of a phenomenon-survival of bodily death. New York: Bantam Books.

Moody, R. A., \& Perry, P. (1988). The light beyond. New York: Bantam Books.

Noyes, R., \& Kletti, R. (1976). Depersonalization in the face of life-threatening danger: An interpretation. Omega (7)2, 103-114.

Platthy, J. (1992). Near-death experiences in antiquity. Santa Claus, IL: Federation of International Poetry Associations of UNESCO.

Plato. (1946). The republic. (P. Shorey, Trans.). London: William Heinemann.

Plutarch. (1969). Moralia (vol. 15). (F. H. Sandbach, Trans.). London: William Heinemann.

Plutarch. (1984). Moralia (vol. 7). (P. H. De Lacy \& B. Einarson, Trans.). London: William Heinemann.

* Throughout this article, references to classical passages are given in full the first time, thereafter only by reference to pages in the translation. 
Ring, K. (1980). Life at death: A scientific investigation of the near-death experience. New York: Coward, McCann \& Geoghegan.

Swedenborg, E. (1928). Arcana coelestia; The heavenly arcana contained in the Holy Scripture or Word of the Lord unfolded; Beginning with the book of Genesis; Together with wonderful things seen in the world of spirits and in the heaven of angels (vol.3). (J. F. Potts, Trans.). New York: Swedenborg Foundation. (Original work published 1749)

The Tibetan book of the dead. (2006). (G. Dorje, Trans.). New York: Penguin.

van Lommel, P. (2007). Eindeloos bewustzijn; een wetenschappelijke visie op de BijnaDood Ervaring [Endless consciousness]. Kampen, The Netherlands: Ten Have.

Zaleski, C. (1987). Otherworld journeys: Accounts of near-death experience in medieval and modern times. Oxford, England: Oxford University Press. 